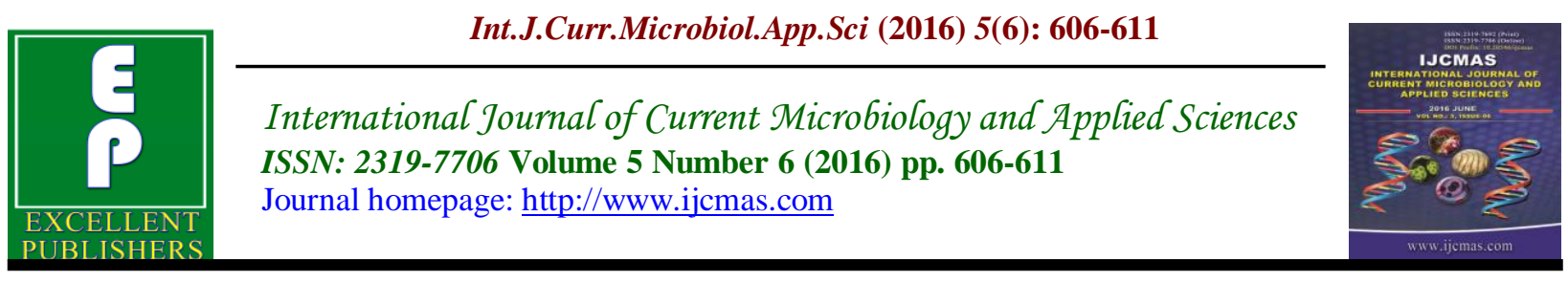

Original Research Article

http://dx.doi.org/10.20546/ijcmas.2016.506.065

\title{
Invitro Assay of Tolerance Limit of Microorganism Isolated from Methyl Parathion Amended Soil
}

\author{
L.B. Sujatha* and Boopathi Mahalaxmi \\ Department of zoology, Pachaiyappa's college, Chennai-30, India \\ *Corresponding author
}

\begin{abstract}
A B S T R A C T
Keywords

Methyl Parathion,

Pesticides,

Soil microbes,

Staphylococcus aureus.

Article Info

Accepted:

20 May 2016

Available Online:

10 June 2016

The present investigation was dealt with the study of tolerance limit of microorganism against various concentration of pesticide methyl parathion from the Indigofera field at Senji near Thindivanam and to isolate the plasmid from the tolerant strain responsible for degradation. The isolates were biochemically identified by standard method of Bergy's Manual of Bacteriology. The microorganism could able to tolerate the highest concentration of Methyl parathion and grow up to $500 \mu 1 / 100 \mathrm{ml}$ of agar medium. The characterized microorganism was found to be Gram-Positive cocci Staphylococcus aureus which fermenting Mannitol salt agar and the plasmid of this strain was isolated by standard method. This investigation would be of great help to found the tolerant strains of microorganism from methyl parathion pesticides and also in future it could be genetically engineered to yield a highly resistant strain which would degrade methyl parathion on a large scale.
\end{abstract}

\section{Introduction}

Organophosphorus pesticides are used worldwide to control major insect pests. These pesticides inhibit acetlylcholinesterase (Ache) in an irreversible manner and cause insect death. As acetlylcholinesterase (Ache) is also present in all vertebrates, the potential for damage by this class of insecticides to nontarget organisms is extremely high and the use of certain organophosphorus pesticides is now banned in most developed countries. However in many developing countries available altenative technologies for the effective replacement of organophosphorus pesticides are limited and consequently they remain the major insecticides in agricultural pest management. This practice poses significant health hazards and organophosphorus pesticide poisoining can occur in rural communities. Furthermore organophosphorus pesticides do considerable damage to the ecosystem and are consequently a major threat to the practice of safe and sustainable agriculture.

Methyl parathion is of low persistence in the soil environment, with reported field halflives of 1 to 30 days (ATSDR, 2001). A representative value is estimated to be 5 days (ATSDR, 2001). The rate of 
degradation increases with temperature and with exposure to sunlight. Methyl parathion is moderately absorbed by most soils, and is slightly soluble in water (ATSDR, 2001). Due to its low residence time and soil binding affinity, it is not expected to be significantly mobile. 4- Nitrophenol, a breakdown product of methyl parathion, does not adsorb well to soil particles and may contaminate groundwater. When large concentrations of parathion reach the soil, as in an accidental spill, degradation will occur only after many years, with photolysis being the dominant route (ATSDR, 2001). Some volatilization of applied methyl parathion may occur.

Methyl parathion degrades rapidly in seawater, lake, and river waters, with $100 \%$ degradation occurring within 2 weeks to 1 month or more. Degradation is faster in the presence of sediments, and is faster in fresh water than in salt water. Complete breakdown occurs at a rate of 5 to $11 \%$ in 4 days in rivers, and more slowly in marine waters. In water, methyl parathion is subject to photolysis, with a half-life of 8 days during the summer and 38 days in winter (ATSDR, 2001). Uptake and metabolism of methyl parathion in plants is fairly rapid. Within 4 days after applying methyl parathion to the leaves of corn, it was almost completely metabolized (ATSDR, 2001).

In contrast, in few cases, Balasubramanian (1974) observed that lindane application increased the nodulation by 2 to 3 times in soybean, Kandasamy et al. (1975) have demonstrated that the population of bacteria and fungi in rhizophere were affected by carbofuran while phorate was stimulatory. $\mathrm{Tu}$ (1970) observed that the rate of oxygen consumption increased with increasing concentration of some organophosphorus insecticides suggesting the possibility of microbial degradation of the insecticides.
Elshahaat et al., (1987) reported the stimulatory effect of aldicarb and carbofuran on carbon dioxide by soil microorganisms.

$\mathrm{Tu}$ (1992) observed degradation of Haloxyfop, Tridiphane and Pyroxyfur by soil microbes. Two strains each of fungi and bacteria contained potent endosulfan degrading enzymes and found to be a valuable source for use in enzymatic bioremediation (Siddique et al., 2003). Pseudomonas species isolated from insecticide-contaminated soil by biphenyl enrichment culture degraded DDT through the intermediate formation of 2,3dihydroxy-DDT ultimately yielding a stable metabolite (Kamanavalli \& Ninnekar, 2004). The fungus, Mucor thermohyalospora was found to involve in both oxidative and hydrolytic pathways for degradation of endosulfan. Similarly, Aspergillus niger transformed endosulfan-to-endosulfan diol (EI Zorganic \& Omer, 1974), while major enzyme sysem in Trichoderma harzianaum was responsible for the transformation of endosulfan to endosulfan sulphate (Katayama \& Matsumara, 1993).

Moreover, the repetitive use of pesticides in agriculture has resulted in human health hazards (Gupta, 1989), pollution to environment (Gunning et al., 1992) and adverse effect on natural enemies (Mathur, 1998). Hence the present study was designed to test microbes on the degradation of methyl parathion.

\section{Materials and Methods}

Microorganisms isolated from the soil collected from the Indigoferra field at Senji near Thindivanam. The glasswares were washed thoroughly and dried. Analytical grade chemicals (Himedia/Merck/Qualigen) were used throughout the study. All media and glasswares used in the study were 
autoclaved at $15 \mathrm{lbs}$ pressure $\left(21^{\circ} \mathrm{C}\right)$ for 20 minutes.

\section{Processing of Soil Sample}

$1 \mathrm{~g}$ of soil sample was weighed and taken in a tube containing sterile distilled water. The tubes were vortexed and $1 \mathrm{ml}$ from it was transferred to the next tube $\left(10^{-2}\right)$. Serial dilutions were performed till $10^{-7} .0 .1 \mathrm{ml}$ of the dilute sample from $10^{-4}$ to $10^{-7}$ was plate on nutrient agar by spread plate technique. The plates were incubated at $37^{\circ} \mathrm{C}$ for $24 \mathrm{hrs}$. The colony was isolated and sub cultured to obtain pure isolate.

\section{Preparation of Treatment Discs and Controls}

Different concentrations (100 to 500 $\mu \mathrm{l}$ ) of methyl parathion were prepared. Sterile discs of $6 \mathrm{~mm}$ diameter were soaked in the pesticides for 18 hours and were completely dried under laminar airflow. Sterile water soaked discs was used as control. Treatments were maintained in duplicates.

\section{Preparation of Plates for Streaking}

Different concentrations $(5 \mu \mathrm{l}$ to $500 \mu 1 / 100 \mathrm{ml}$ of medium) of methyl parathion were mixed well with the Nutrient agar medium and poured into petriplates.

\section{Bioassay for Streak Plate Method}

The plates were streaked and qualitatively analysed by the method of Ellaiah et al. (2002).

\section{Bioassay for Disc-diffusion assay}

Sterile agar plates were poured and dried. The OD of the inoculum was adjusted using McFarland standard and the desired amount is added to the plates. A lawn was made using a sterile spreader. Using a template, the discs were placed equidistantly from each other. Separate positive control (antibiotics) simultaneously placed and incubated overnight at $37{ }^{\circ} \mathrm{C}$. The zones of inhibition if any were measured (Sharma \& Govindaiah, 1991).

\section{Bacterial Characterization}

Morphological, physiological and biochemical properties of the bacterial strain that included gram staining, motility test, catalase test, oxidase test and selective media such as Mannitol salt agar test was determined as per the standard methods according to Bergy's Manual of Determinative Bacteriology (Holt et al., 1994).

\section{Plasmid Isolation}

The highly tolerant strains were isolated and inoculated in liquid broth and kept for $24 \mathrm{hrs}$ incubation. The pellets were separated by centrifugation $(6000 \mathrm{x} \mathrm{g}$ for $10 \mathrm{~min}$ ) and treated with solution A $(25 \mathrm{mM}$ Tris HCL, $50 \mathrm{mM}$ glucose, Lysozyme, distilled water), solution B $(0.2 \mathrm{M} \mathrm{NaoH}$, SDS, Distilled water), solution C (3M sodium acetate, distilled water) solution D $(50 \mathrm{mM}$ Tris HCL, 100Mm sodium acetate, distilled water) and kept for incubation on ice for $1 \mathrm{hr}$. Supernatant was collected after centrifugation and treated with ethanol and incubated in freezer for overnight. The pellets were collected and analysed by the method of Brinboim \& Doly, 1979.

\section{Results and Discussion}

\section{Bioassay}

The present study was interested to test the tolerance limit of microorganism to different concentration of methyl parathion and to isolate the plasmid from the resistant strain. 


\section{Streak Plate Method}

Table 1 showed the different concentrations of methyl parathion in Nutrient agar medium were tested for the tolerance limit of microorganism. The microbe was able to tolerate and grow up to $500 \mu \mathrm{l}$ per $100 \mathrm{ml}$ medium (Ellaiah et al., 2002).

\section{Disc Diffusion Assay}

Different concentrations $(100-500 \mu \mathrm{l})$ of methyl parathion were tested against microorganism using sterile disc method. The results obtained proved that methyl parathion could not inhibit the growth of microorganism (Table 2).
Characterisation and Identification of bacterial strains

The bacterial strains were characterized and identified using standard morphological, physiological and biochemical tests. The bacterial strains were found to be Grampositive cocci in single, pairs, clusters and motile cocci were seen. Some organisms were found to be positive for catalase test and negative for oxidase test. Small yellow colonies were observed on Mannitol salt agar plate method. The organism was found to be Staphylococcus aureus.

Table.1 Tolerance limit of microorganism against different concentration of methyl parathion by streak plate method.

\begin{tabular}{|c|c|}
\hline Concentration $(\boldsymbol{\mu l} / \mathbf{1 0 0 m l}$ medium $)$ & Inhibition $(\mathbf{m m})$ \\
\hline 5 & + \\
\hline 50 & + \\
\hline 75 & + \\
\hline 100 & + \\
\hline 250 & + \\
\hline 500 & + \\
\hline
\end{tabular}

'+’ No Inhibition.

Table.2 Tolerance limit of microorganism against different concentration of methyl parathion by disc diffusion assay.

\begin{tabular}{|l|c|c|c|}
\hline $\begin{array}{l}\text { Particular } \\
\text { s }\end{array}$ & \multicolumn{3}{|c|}{ Different concentrations of pesticides $(\boldsymbol{\mu l})$} \\
\hline $\begin{array}{l}\text { Methyl } \\
\text { parathion }\end{array}$ & 100 & 300 & 500 \\
\hline Growth & + & + & + \\
\hline
\end{tabular}

'+' No Inhibition. 
Soil organisms are responsible for contributing to the decomposition of dead animal and plant material into organic matter, an important component of our soil fraction. Others are involved in the natural control of soil pests. Aside from their direct effects on pest organisms, soil microbes are a major agent in degrading pesticides. The breakdown of pesticides is beneficial for crop rotation and food residue concerns, and provides herbicide selectivity in some instances. The value of certain soil bacteria that have a symbiotic relationship with leguminous plants in fixing nitrogen translates into reduced synthetic nitrogen fertilizer inputs and increased crop yields. Fortunately, the effect of soil-applied pesticides is short-lived; in fact, in some instances they may enhance the population of certain soil microorganisms.

Many other organoposphate pesticides are susceptible to enhanced degradation in soil such as isofenophos, fenamiphos, ethoprophos, diazinon, fensulfothion, parathion and methyl parathion, but there have been very few reports of enhanced degradation of methyl parathion. There have, however, been reports of different rates of degradation of methyl parathion in soils, with a half-life range from few days to moths. In the experiments, the rate of degradation of methyl parathion was observed.

Organophosphorus pesticide has been reported previously to be resistant to enhanced degradation, due to the accumulation in soil of the antimicrobial degradation product TCP. In the present experiments, an increase in pretreatment concentration of TCP in soil reduced the degradation rate of chlorpyriphos, although concentrations greater than $25 \mathrm{mg} \mathrm{kg}^{-1}$ were required before this occurred. An increase in TCP concentration also reduced the degradation rate of TCP itself which supports the earlier report of a possible toxic effect of this compound on the soil microbial community (Racke et al., 1990). However, when organophosphorus pesticide is used repeatedly over an years, some opportunist microorganisms may well develop the capability to use this toxic compound, as has been reported with organochlorine compounds this adaptation can provide strains with a competitive advantage over other microbes in terms of sources of energy.

Earlier study on organophosphorus pesticide reported that complete mineralization of chlorpyriphos in the Australian soil appeared to result from the activities of both fungal and bacterial components of the soil micro flora. Both antifungal and antibacterial agents affected the rate of degradation. The results from the mineralization experiment suggested that soil bacteria mainly brought about chlorpyriphos degradation. Chloramphenicol had no effect on mineralization rate, but the presence of kanamycin and trimethoprim in soil had a strong adverse effect, suggesting that chloramphenicol-resistance bacteria were responsible for degradation. Pretreatment of soil with TCP up to $100 \mathrm{mg}$ $\mathrm{kg}^{-1}$ had no effect on the rate of degradation of chlorpyriphos in the enhanced Australian soil, suggesting that a robust chlorpyriphosdegrading population had developed.

\section{References}

Agency for Toxic substances and Disease Registry (ATSDR, 2001). Managing Hazardous Materials Incidents, Volume 3-Medical Management Guidelines for Acute Chemical Exposure: Methyl Parathion. Atlanta, GA: U.S. Department of Health and Human Service, Public Health Service.

Balasubramanian, A. 1974. Effect of lindane 
on radiocarbon incorporation by Rhizobium joponicum. Paper presented in the symposium on use of radiation and radioisotopes in studies of plant productivity held at Pant Nagar, April 12-14.

Brinboim, H.C., J. Doly. 1979. A rapid alkanline extraction procedure for screening recombinant plasmid DNA. Nucl. Acids. Res., 7: 1513-23.

Ellaiah, P., Raju, K.V., Adinarayana, K., Adinarayana, G., Prabhakar, T., J. Premkumar. 2002. Bioactive rare Actinomycetes from indigenous natural substrates of Andhra Pradesh. Industan Antibiot Bull., 44: 17-24.

Elshahaat, M.S., Othman, M.A.S., EI Haifwy, M., Marei, A.S. 1987. Effect of carbamate and synthetic pyrethrroid pesticides on some soil microbial activities. J. Agri. Res., 32: 427-38.

EI Zorgani, G.A., M.E.H. Omer. 1974. Bull. Environ. Contam. Toxicol., 12: 182-185.

Gunning, R.V., Balfe, M.E., Easton, C.S. 1992. Carbamate resistance in Helicoverpa armigera (Hubner) (Lepidoptera: Noctuidae) in Australia. Aust. Entomol. Soc., 31: 97-103.

Gupta, Y.P. 1989. Pesticides poisoning. Sci. Res., 26: 491-492.

Holt, J.G., Kreig, N.R., Sneath, P.H.A., Staley, J.T., Willams, S.T. 1994. Bergy's Manual of Determinative Bacteriology. $9^{\text {th }}$ Edn., Lippincott Williams and Wilkins, Baltimore, USA., ISBN-13:970683006032,pp:787.

Kamanavalli, C.M., Ninnekar, H.Z. 2004. Biodegradation of DDT by a
Pseudomonas species. Curr Microbiol., 48: 110-13.

Kandasamy, D., Marimuthu, T., Rajkannu, K., Raghuraj, R. Oblisami G., Krishnamoorthy, K.K., Subramanium, T.R. 1975. A study on the relationship between the dissipation of insecticides and rhizosphere micro flora of paddy. Madras Agri. J., 62: 203-207.

Katayama, A., F. Matsumara. 1993. Environ. Toxicol. Chem., 12: 1059-1065.

Mathur, S.C. 1998. Pesticide industry in India. Pesticide information, 23: 117-19.

Racke, K.D., Laskowski, D.A., Schltz, M.R. 1990. Resistance of chlorpyriphos to enhanced biodegradation in soil. $J$. Agric. Food Chem., 38: 1430-1436.

Sharma, D.D., Govindaiah. 1991. Comparative in vitro toxicity of fungicides against Pseudomonas mori (Boyer and Lambert) Stevens causing bacterial blight of mulberry. Indian $J$. Sericulture, 30(2): 139-140.

Siddique, T., Okeke, B.C., Arshad, M., Frankenberger, W.T. 2003. Enrichment and isolation of endosulfan degrading microorganisms. Environ. Qual. Jan., 32: 47-54.

$\mathrm{Tu}$, C.M. Effect of four organophosphoric insecticides on microbial activities in soil. Appl. Microbiol., 19: 479-484.

Tu, C.M. 1992. Effect of three newer pesticides on microbial and enzymatic acivities in soil. Bull. Environ. Contamination and Toxicol., 49: 120128.

\section{How to cite this article:}

Sujatha, L.B., and Boopathi Mahalaxmi. 2016. Invitro Assay of Tolerance Limit of Microorganism Isolated from Methyl Parathion Amended Soil. Int.J.Curr.Microbiol.App.Sci. 5(6): 605-611. doi: http://dx.doi.org/10.20546/ijcmas.2016.506.065 